\title{
Effect of Public Expenditure in Construction and Transportation sectors on Employment in Nigeria
}

\author{
EWUBARE, Dennis Brown \&MAEBA, Sampson Lucky \\ Rivers State University, Department of Agricultural and Applied Economics, Faculty of Agriculture, Port \\ Harcourt, Nigeria
}

\begin{abstract}
This paper examined public expenditure and employment in Nigeria from 1980 to 2017. The study was induced by the insufficient federal government budgetary allocations to some critical sectors such as transport and construction sectors that tend to prompt the decay in the construction sector. To this end, the objectives of the study are to evaluate the effect of public expenditure in construction and transport sectors on employment rate in Nigeria. In doing this time series data were collected from CBN bulletin from 1980-2017 on variables such as employment rate, public expenditure on construction and transportation sectors. The cointegraton and ECM methods were used for the analysis. The long run dynamic results showed that there exists a long-run relationship or equilibrium among the variables. The coefficient of ECM is negatively signed and statistically significant at 5 percent level. Meaning that the short run error has been adjusted to long run equilibrium relationship. The result of analysis showed that in the long run, government expenditure will address the pitfalls in the country employment. Therefore, the paper recommended that effort should be made to ensure viability of social infrastructure through increase in annual capital budget spending in order to increase the level of employment and hence economic growth in Nigeria.
\end{abstract}

KEY WORDS: Employment, Expenditure, Construction, Transport, Sector

\section{INTRODUCTION}

One of the macroeconomic objectives of every economy is achievement of full employment. Full employment does not necessarily mean absence of unemployment but to a large extent minimal level of unemployment. Thus, unemployment is a situation whereby people who are willing and capable to work at the prevailing wage rate cannot find work to do (Gbosi, 2015). Rising level of unemployment is usually accompanied by social vices especially among young people and this threatens the foundation of a nation. Therefore, governments at various levels have adopted measures to create employment. One of such measures is public expenditure. Public expenditure is the aspect of the economics which deals with government revenue and spending as well as the adjustment of one or the other to achieve the desirable effect and avoid the undesirable ones(Obayori, 2016). One of the desirable effects is employment generation.

Employment is generated when job opportunities are provided by the government through government expenditure in the provision of social and economic infrastructures in the economy. This implies that the provision of infrastructural facilities through public funds has dual purpose of generating employment opportunities directly while at the same time using the amenities towards encouraging the productive sectors in order to provide employment opportunities for the teaminglabour force (Abdullahi, 2010; Jhinghan, 2008).

In Nigeria, public finance has been extremely pro-cyclical with expenditure rocketing out of control on the uprising of the oil price cycle. By extension, the upsurge in the expenditure of Government is expected amongst others to 
International Journal of Science and Management Studies (IJSMS)

Volume: 01 Issue: 04
November to December 2018
E-ISSN: 2581-5946

www.ijsmsjournal.org

generate sizeable level of employment. Contrary to the above, over the years, government spending in Nigeria on productive sectors such as telecommunication, transportation and construction has been a mismatch with the level of generated revenue from both the oil and non-oil sectors. This is so because of persistent decreasing level of employment in the country. For instance, as a result of little fraction of the annual budget, budgeted for the transport sector, most of the roads in the nation are in bad shape and the airport are sub- standard when compared to some developed or developing countries. This led to accident and loss of lives and properties. Similarly, available statistics from CBN (2016) showed that increased government expenditure in the construction sector has been on the increase in Nigeria over time. For instance, average government expenditure on construction sector increased from 0.26 billion naira in 1980/1989, to 3.24 billion naira in 1990/1999, to 33.59 billion naira $2000 / 2009$ and to 14189.95 billion naira in 2010/2016. But the increase has not translated into increase in employment and economic growth at large.

In sum, the above statistics at least suggests the existence of high unemployment in Nigeria today. The NBS (2014) reported that unemployment rate rose from less than $10 \%$ in the early 1980 s to $23.9 \%$ in 2013 . According to Oaikhenan and Aigheyisi (2015), efforts by government at job creation such as NEEDS, SEVEN POINT AGENDA and SURE-P appear to have yielded very little result. Thus, emphasis has been on the need for government to expand its spending in the critical sectors particularly, construction and transportation to stimulate the economy. It is against this background that the paper analyzed the effect of public expenditure in construction and transportation sectors on employment rate in Nigeria.

\section{LITERATURE REVIEW}

Theoretically, the study was be based on Keynesian theory of employment, which is a reflection of the functionally relationship input through labour and capital to generate output. Meaning that Keynesian theory of employment examines the connection between public expenditure and growth through employment generation.

According to Keynes (1939), public expenditures can contribute positively to economic growth by increasing government consumption through increase in employment, profitability and investment. This theory believes that active government intervention in the market place through government expenditure was the only method for ensuring full employment by ensuring efficiency in resource allocation and regulation of markets.

Empirically, Michele (2005) examined the dynamic effects of fiscal policy shocks on government employment in the US economy. The study revealed indirect and direct shocks for both employment and private output respectively. In like manner, Fasoranti (2012) examined the effect of government expenditure on infrastructure on the growth of Nigeria economy. She used government expenditures on education, environment and housing, health services, water resources, inflation rate, agriculture, security, transport and communication. The paper observed that expenditures on health services, transport and communication imparted negatively on growth while expenditures in agriculture and security were not significant in the growth of the economy.

Danjuma and Bala (2012) explored the role of governance in employment generation in Nigeria. The study employed primary data obtained through the use of interviews. The findings of the study showed that low employment rate in Nigeria had created tension and hatred between the haves and have-not leading to communal clashes; resulted in the emergence of militant groups (like the Boko Haram sect and Niger Delta militants), prostitution, armed robbery and child trafficking, constituting hiccups to security of lives and properties.

Oke (2011) used correlation analysis to assessed the effect of fiscal policy on construction works in Nigeria from 1980-2006. He observed that there is a positive correlation between taxation, government expenditure and construction sector.

Using three-stages of Least Squares Method (LSM), Onakoye, Tella and Osoba (2012) examine the relationship between investment in telecommunication infrastructure and economic growth in Nigeria. The study found that 
telecommunication infrastructural investment has a significant impact on output of the economy directly through its industrial output and indirectly through the output of other sectors such as agriculture.

Using the OLS regression analysis to assessed public expenditure in road infrastructure and output in Nigeria, Nworji\&Oluwalaiye (2012) averred that there is a direct and significant relationship between transport, communication and economic growth. Similarly, Estache and Garsous (2012) used content analysis to examine the impact of government expenditure on infrastructure sector and job creation in developing economies. Their findings showed that there is a direct link between infrastructural investment and employment in the industrial sector of the economy and indirect in other sectors. Edame (2014) studied the determinants of public infrastructure spending in Nigeria using ECM. He found that rate of urbanization; government revenue population density, external reserves, and type of government influence public expenditure on infrastructure in Nigeria.

Abdullahi (2010) examined the impact of government expenditure on employment generation in Nigeria for a period of 1980-2014 with the use of Vector Error Correction Model. The overall result revealed that agriculture expenditure and road construction expenditure have insignificant and negative effect on rate of employment while transport expenditure and education expenditure have positive significant effect on rate of employment.

In a time series study on the impact of government spending in critical sectors such as transportation, communication and construction on economic growth in Nigeria. Using theEngle-GrangercointegrationandErrorCorrectionModelingtechniques, Charles, Tamuno and Onuchuku (2018) revealed that government expenditure on construction; transport and communication have a negative relationship with economic growth and also do not impact on it.

\section{METHODOLOGY}

The paper adopts quasi-experimental research design. The study was mainly quantitative research based on regression analysis. The data for the study was essentially sourced from publications of the Central Bank of Nigeria (CBN) statistical bulletin from 1980-2017.This study adopts both descriptive statistics and econometrics approaches. The descriptive statistics was used to analyse the trend in the data. The Augmented Dickey Fuller test (ADF) was employed to test for the stationarity of the time series (Dickey \& Fuller, 1979). Again, co-integration do to Johansen (1998) is used to test for the long run relationship among the variables in the model. Error Correction modeling approach was used to correct the pitfalls of the short run model. Other tests conducted to ascertain the authenticity of the pre estimation test are normality test and autocorrelation test

\section{Model Specification}

Theoretically, the model was based on Keynesian theory of employment which relates employment with investment. Functionally, the ECM model was represented as follow:

$\mathrm{EPG}=\beta_{0}+\Sigma \beta_{1 \mathrm{t}} \mathrm{EPG}_{\mathrm{t}-1}+\Sigma \beta_{2 \mathrm{t}} \mathrm{PXC}_{\mathrm{t}-1}+\Sigma \beta_{3 \mathrm{t}} \mathrm{PXT}_{\mathrm{t}-1}+\pi_{1} \mathrm{ECM}_{\mathrm{t}-1}+\mathrm{U}(1)$

Where; EPG is the dependent Variable, PXC, PXT are the explanatory variables, EPG is Employment Rate, PXT is Public Expenditure in the Transport sector, PXC is Public Expenditure in Construction Sector, $\pi_{1}$ is the coefficient of ECM which measure the speed of adjustment of the model and $U$ is the error term.

\section{Empirical Results and Discussion}

The empirical analysis focused mainly on descriptive statistics, estimation of the regression model and post estimate tests. 
Table 1: Descriptive Statistics for Underlying Series

\begin{tabular}{|l|c|c|c|}
\hline & EPG & PXT & PXC \\
\hline Mean & 12.34237 & 24033.95 & 34231.71 \\
\hline Std. Dev. & 4.476434 & 27334.23 & 48981.13 \\
\hline Skewness & 0.776374 & 0.842436 & 1.448959 \\
\hline Kurtosis & 3.072136 & 2.491109 & 4.397908 \\
\hline Jarque-Bera & 3.825702 & 4.904793 & 16.39078 \\
\hline Probability & 0.147659 & 0.086087 & 0.000276 \\
\hline
\end{tabular}

Source: Researcher's Computation from (E-view 9)

The descriptive statistics reported in Table 1 indicated that employment rate (EPG),Public Expenditure in the Transport sector(PXT) and Public Expenditure in Construction Sector (PXC) averaged 12.43\%, $\$ 24033.95$ million and $\$ 34231.71$ million respectively. The standard deviation value showed that while, the dependent variable (employment rate) does not converge around it means, the independent variables converge around their respective means. The kurtosis test showed that all the series have thin tails. The probability of Jarque-Bera statistics indicated that the alternative hypothesis of normal distribution for employment rate, public expenditure in the transport sector were rejected at 5\% level while the alternative hypothesis of public expenditure in construction sector was accepted.

Table 2 Augmented Dickey Fuller Unit Root Test at Level and First Difference

\begin{tabular}{|c|c|c|c|c|c|c|c|c|c|}
\hline \multirow[b]{2}{*}{ Variable } & \multirow{2}{*}{$\begin{array}{l}\text { ADF } \\
\text { Test@ } \\
\text { Level }\end{array}$} & \multicolumn{3}{|c|}{ Critical Value } & \multirow{2}{*}{$\begin{array}{l}\text { ADF } \\
\text { Test@ } 1^{\text {ST }} \\
\text { Diff }\end{array}$} & \multicolumn{3}{|c|}{ Critical Value } & \multirow{2}{*}{$\begin{array}{l}\text { Integration } \\
\text { Order }\end{array}$} \\
\hline & & $1 \%$ & $5 \%$ & $10 \%$ & & $1 \%$ & $5 \%$ & $10 \%$ & \\
\hline EPG & -1.3074 & -3.6267 & -2.9458 & -2.6115 & -9.2664 & -3.6267 & -2.9458 & -2.6115 & $1(1)$ \\
\hline PXT & 0.0419 & -3.6210 & -2.9434 & -2.6102 & -6.0537 & -3.6267 & -2.9458 & -2.6115 & $1(1)$ \\
\hline PXC & 0.0331 & -3.6329 & -2.9484 & -2.6128 & -7.9483 & -3.6329 & -2.9484 & -2.6128 & $1(1)$ \\
\hline
\end{tabular}

Source: Researcher's Computation from (E- view 9)

The order of integration of each of the series as presented in Table 2 using the ADF tests showed that all the variables were not stationary at level. Thus, the variables were subjected to first difference and they became stationary at first difference. Given the stationarity of the variables, the best regression results will be obtained when estimating both co-integration and error correction model.

Table 3 Johansen Co-integration Test Result

\begin{tabular}{|c|c|c|c|c|}
\hline Eigen value K=1, $\mathbf{r = 2}$ & Trace Statistics & $\mathbf{5 \%}$ critical value & Prob. $* *$ & Hypothesis of CE(s) \\
\hline 0.848672 & 159.1518 & 95.75366 & 0.0000 & None * \\
\hline 0.232946 & 11.17334 & 10.49471 & 0.0211 & At most $1^{*}$ \\
\hline 0.044168 & 1.626228 & 3.841466 & 0.2022 & At most 2 \\
\hline
\end{tabular}

Note: $r=$ number of co-integrating vectors and $k=$ number of lags in model. $*$ rejection of the $\mathrm{HO}$

Source: Researcher's Computation from (E- view 9) 
The Johansen co-integration test results as reported in Table 3showed that there are two co- integrating equations at $5 \%$ level of significance. Thus, an equilibrium relationship in the long run exists amongst the series. Given that there are two co-integrating equations, the requirement for fitting in an error correction model is satisfied.

\section{Table 4: Parsimonious Error Correction Mechanism}

\begin{tabular}{|c|r|r|r|r|}
\hline Dependent Variable: D(EPG) & & & \\
\hline Variable & Coefficient & Std. Error & t-Statistic & Prob. \\
\hline C & 7090.237 & 4047.382 & 1.751808 & 0.0989 \\
\hline D(EPG(-1)) & 0.318403 & 0.189640 & 1.678990 & 0.1126 \\
\hline DLOG(PXT) & 0.055007 & 0.788055 & 0.069800 & 0.9450 \\
\hline DLOG(PXC) & 1.109675 & 0.416292 & 2.665619 & 0.0138 \\
\hline ECM(-1) & -0.119174 & 0.049012 & -2.430060 & 0.0073 \\
\hline R-squared & 0.5524 & Adjusted R-squared & & 0.3864 \\
\hline F-statistic & 4.0079 & S.D. dependent var & 2.5925 \\
\hline Prob(F-statistic) & 0.0124 & Durbin-Watson stat & 1.7593 \\
\hline Source:
\end{tabular}

Source: Researcher's Computation from (E- view 9)

The results of the parsimonious error correction model presented in Table 4showedthat the coefficient of ECM has the hypothesized negative sign and is statistically significant at $5 \%$ level with the speed of adjustment 0.11917 per year, which implies that about $11.9 \%$ of the disturbance in the short run is corrected each year. Also, the $\mathrm{R}^{2}$ of $55 \%$ showed that the model is a good fit. Thus, 55 percent variation in employment rate is explained by the changes in the both public expenditure in the transport construction Sectors. The Durbin Watson statistics value of 1.759 suggested that the model is free from positive serial correlation. Also, the f-statistic value of 4.0079 with probability value of 0.01243 showed that all the explanatory variables are significant in explaining increase in the level of employment in Nigeria during the period of study.

The coefficient of current value of employment rate is positively related with the previous value of employment rate but not statistically significant. Also, the coefficient of government expenditure in the transport sectorshowed that a percentage increase in government expenditure in the transport sector increases the level of employment by 5.5007percent. Meanwhile, government expenditure in the transport sector is not statistically significant with employment rate. The finding support Amadi, Amadi and Nyenke (2013), who averred that public expenditure in transport sector, has a direct relationship with economic growth via employment generation.

The coefficient of government expenditure in the construction sectorshowed that a percentage increases in government expenditure in the construction sector increases the level of employment by 26.676 percent. Meanwhile, government expenditure in the construction sector is statistically significant with employment rate. The finding supported the view of Ighodaro (2009) who opined that construction sector facilitate the direct provision of services to consumers, it also provides intermediate inputs for other productive sectors and raise factor productivity.

Table 5: Results of Post-Estimation Tests

\begin{tabular}{lll}
\hline Test type & Test stat. & p-value \\
\hline Serial correlation test (Breush-Godfrey LM test & $X^{2}$-stat & 0.2250 \\
Normality Test & JarquaBera & 0.8949 \\
\hline
\end{tabular}

Source: Created by the Author Using E-views 9 
International Journal of Science and Management Studies (IJSMS)

Volume: 01 Issue: 04
November to December 2018
E-ISSN: 2581-5946

www.ijsmsjournal.org

The serial correlation Lagrange multiplier (LM) test result showed that in the employment model, serial autocorrelation is also not a problem. This is because the chi-square value of 1.01 and the corresponding probability value of $(0.225)$ of the chi-square statistic exceed the 0.05 . The normality test also showed that the error terms are normally distributed. Thus, the analysis of the post estimation tests are welcoming as they meet the statistical criteria and authenticate the reliability of the estimated model for policy formulation and recommendation.

\section{CONCLUSION}

This study examines the effect of public expenditure on Nigeria's employment from 1980 to 2017. The study was induced by the insufficient and fluctuatory federal government budgetary allocations to some critical sectors such as transport and construction sectors that tend to prompt the existence of deteriorate transportation standards as well as decay in the construction sector. To this end, the broad objective of the study is to evaluate the effect of public expenditure on employment rate in Nigeria. In doing this time series data were collected from CBN bulletin from 1980-2017 on variables such as employment rate, public expenditure on construction, and transportation sectors. The cointegraton and ECM methods were used for the analysis. The long run dynamic results showed that there exists a long-run relationship or equilibrium among the variables. This is because the coefficient of ECM is negatively signed and statistically significant at 5 percent level. Meaning that the short run error has been adjusted to long run equilibrium relationship. The result of analysis showed that in the long run, government expenditure will address the pitfalls in the country employment. This therefore showed that proper implementation of economic reforms that would improve employment level through improved transport services in the country will go a long way to enhance employment rate and development in Nigeria. In conclusion, fiscal policy via public expenditure remains crucial in the process of employment generation. Efforts should therefore be made to ensure viability of social infrastructure through increase in annual capital budget spending in order to increase the level of employment and hence economic growth in Nigeria.

\section{REFERENCES}

[1] Abdullahi, S. A. (2010). Impact of Government Expenditure on Employment Generation: Evidence from Nigeria. Department of Financial Studies Faculty of Management Sciences National Open University of Nigeria, Lagos. Retrieved online, March, 2016

[2] Central Bank of Nigeria (2016).Statistical Bulletin, Abuja,Central Bank of Nigeria.

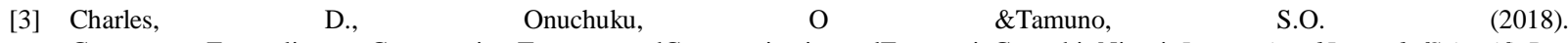
GovernmentExpenditureonConstruction,TransportandCommunicationandEconomicGrowthinNigeriaInternationalJournalofScientificRes earch,3(2), 39-47

[4] Danjuma, A. \&Bala, A. K. (2012). Role of Governance in Employment Generation in Nigeria, Journal of Business and Management, 3(3), 27-31.

[5] Dickey, D.A., \& Fuller, W.A. (1979).Distribution of the Estimators for Autoregressive Time Series with a Unit Root.Journal of the American Statistical Association.74(1), 427-431.

[6] Edame, G.E. (2014). Public Infrastructure Spending and Economic Growth in Nigeria: An Error Correction Mechanism (ECM) Approach. Journal of Social Economics Research, 1(7), 129-140.

[7] Estache, A. \&Garsous, G. (2012).The scope for an impact of infrastructure investments on jobs in developing countries, International Finance Corporation EconomicsNote 4. Retrieved on May 20, 2016 from http://www.ifc.org/wps/wcm/connect/32da92804db

[8] Fasoranti, M. (2012).The effect of Government Expenditure on Infrastructure on the Growth of the Nigeria Economy (1977-2009). International Journal of Economics and Financial Issue, 2(4), 513-518.

[9] Gbosi, A. N. (2015). Contemporary Macroeconomic Problems and Stabilization Policies. Port Harcourt: Automatic Ventures.

[10] Jhingan, M. L. (2008): Monetary Economics, Sixth Edition, Delhi: Vrinda Publications Ltd.

(C) 2018, IJSMS Page 135 
International Journal of Science and Management Studies (IJSMS)

Volume: 01 Issue: 04
November to December 2018
E-ISSN: 2581-5946

\section{www.ijsmsjournal.org}

[11] Johansen, S. (1998).Statistical Analysis and Co-integrating Vectors. Journal of Economic Dynamics and Control, 12(2-3), $231-254$.

[12] Keynes, J. M. (1936). The General Theory of Employment, Interest and Money. London and New York, Macmillan.

[13] Mitchell, D. J. (2005).The Impact of Government Spending on Economic Growth.Heritage foundation backgrounder No. 1831.

[14] National Bureau of Statistics (2014). Annual Publications, Abuja: NBS.

[15] Nworji, I. D. \&Oluwalaiye, O. B. (2012).Government Spending on Road Infrastructure and its Impact on the Growth of Nigerian Economy. International Journal of Management \& Business studies, 1(2),24-30.

[16] Oaikhenan, H. E. \&Aigheyisi, O. S. (2015).Investment, Government Expenditure and Unemployment in Nigeria. The Nigerian Journal of Economic and Social Studies, 57(2), 201-223.

[17] Obayori, J.B. (2016). Fiscal Policy and Unemployment in Nigeria. The International Journal of Social Sciences and Humanities Invention.3(2), 24-35

[18] Oke, A. (2012). Effect Of Fiscal Policy On Nigerian Construction Sector, Journal of Surveying, Construction \& Property, 2(1),1-10

[19] Onakoye, B. O. A., Tella, A. S. \&Osoba, M. A. (2012), Investment in Telecommunications Infrastructure and Economic Growth in Nigeria: A Multivariate Approach. British Journal of Economics, Management and Trade, 2(4), 309-326. 